\title{
ARTIKKELIT
}

\section{Miksi muistisairaiden läheiset eivät käytä palveluja?}

\author{
Ulla Halonen $^{1}$ \\ ${ }^{1}$ Yhteiskuntatieteiden ja filosofian laitos, Jyväskylän yliopisto
}

\begin{abstract}
Muistisairaita läheisiään hoivaavilla on merkittäviä tuen ja palveluiden tarpeita, joten on ristiriitaista, että he eivät välttämättä käytä saatavilla olevia palveluja. Tässä tutkimuksessa tarkastellaan syitä, joiden vuoksi läheiset eivät käytä palveluja. Tutkimuksen aineisto $(n=45)$ kerättiin puhelinhaastatteluilla eri puolilta Suomea asuvilta läheisiltä; 25 heistä oli puolisoita ja 20 aikuisia lapsia. Haastattelut litteroitiin ja aineisto analysoitiin teoriaohjaavalla sisällönanalyysillä. Haastateltujen läheisten mukaan suurin syy olla käyttämättä palveluja on se, että sairastunut itse ei halua palveluja eikä myöskään suostu siihen, että läheiset hankkivat niitä. Toinen keskeinen syy on se, että läheiset kokevat palvelujen olevan riittämättömiä, huonolaatuisia tai joustamattomia. Näiden lisäksi etenkin puolisohoivaajilla on henkilökohtaisia syitä palvelujen käyttämättä jättämiselle. Kaiken kaikkiaan puolisoilla on aikuisia lapsia enemmän syitä, joiden vuoksi he eivät käytä palveluja. Tulokset osoittavat, että erityisesti muistisairaiden puolisot tarvitsevat rohkaisua ja kannustusta palvelujen käyttöön oman hyvinvointinsa ja jaksamisensa tukemiseksi. Palvelujärjestelmää on myös kehitettävä vastaamaan paremmin läheisten kokemia tarpeita.
\end{abstract}

\section{Johdanto}

Muistisairaus on merkittävin hoivan tarpeita aiheuttava sairaus (Finne-Soveri 2015). Suomessa on tavoitteena, että ikääntyneet - ja siten myös muistisairaat - asuisivat mahdollisimman pitkään kotona. Tämä ei olisi useinkaan mahdollista ilman läheisiltä saatavaa tukea. Läheisten onkin usein todettu julkisten palveluiden sijaan tai ohella vastaavan hoivapalvelujen tarpeisiin (Heikkilä ym. 2020; Halonen ym. 2021). Erityisesti lähisukulaisten merkitys on tärkeä: eniten hoivaa antavat puolisot ja aikuiset lapset (esim. Kröger \& Yeandle 2013).
Sairastuneen lisäksi myös läheinen tarvitsee tukea; tuen riittämättömyyden on todettu koskevan jopa enemmän läheisiä kuin sairastuneita (Van Aerschot ym. 2021). Tuen tarpeista huolimatta läheisillä on moninaisia syitä olla käyttämättä palveluja (esim. Phillipson ym. 2014). Tämän tutkimuksen tarkoituksena on kuvata kansallisella tasolla syitä, jotka estävät muistisairauteen sairastuneiden läheisiä hankkimasta tai käyttämästä palveluja.

Suomessa muistisairauteen sairastuu vuosittain arviolta 14500 ihmistä, ja kaikkiaan muistisairaita arvioidaan olevan 200000 (Tommola ym. 2021). Väestön ikääntyessä muistisairaiden määrän ennakoidaan kolminkertaistuvan vuo- 
teen 2050 mennessä maailmanlaajuisesti (ADI 2019). Muistisairaus on kattokäsite sairauksille, jotka vaikuttavat muistiin ja kognitiivisten toimintojen heikkenemiseen. Yleisimmät etenevät muistisairaudet ovat Alzheimerin tauti ja aivoverenkiertosairaudet. Lähimuistin heikkenemisen ohella tyypillisiä oireita ovat uuden oppimisen vaikeutuminen sekä toiminnanohjauksen ja asioiden organisointikyvyn heikentyminen. Monet muistisairaudet aiheuttavat myös erilaisia neuropsykiatrisia oireita, joista tavallisimpia ovat masennus, harhaluuloisuus ja aistiharhat. Sairauden oireet ja ilmeneminen ovat yksilöllisiä, mutta sairastuneet saattavat tarvita apua arjesta selviytymiseen jo sairauden varhaisessa vaiheessa. (Muistisairaudet: Käypä hoito -suositus 2020.) Lisäksi sairastuneen kyky tiedostaa sairautensa oireet voi olla puutteellinen (Juva 2014). Sairastuneen muuttunut käytös ja seurannan tarve vaikuttavat osaltaan läheissuhteisiin ja lisäävät läheisten kokemaa kuormitusta (esim. Sointu 2011; Stolt ym. 2014; Connors ym. 2020).

Palveluilla tarkoitetaan tässä tutkimuksessa julkisia ja yksityisiä palveluja sekä kolmannelta sektorilta saatavaa tukea. Tutkimuskysymykset ovat:

1) Miksi muistisairaiden läheiset eivät käytä saatavilla olevia tai tarvitsemiaan palveluja?

2) Miten puolisoiden ja aikuisten lasten syyt olla käyttämättä palveluja eroavat toisistaan?

\section{Läheisten tuen tarpeet}

Muistisairauden tuomien muutosten on todettu vaikuttavan monin tavoin sairastuneen läheisten elämään ja aiheuttavan heille kuormitusta (esim. Wennberg ym. 2015). Aikaisempien kirjallisuuskatsauksien pohjalta tiedetään, että läheisillä on esimerkiksi merkittäviä psyykkisiä ja fyysisiä terveysongelmia (esim. Chiao ym. 2015). Muistisairaan hoitaminen on läheiselle monimutkainen kokemus, joka sisältää vaihte- levien käytännön haasteiden lisäksi emotionaalisia ja moraalisia paineita (Tolhurst ym. 2019). Ei olekaan ihme, että sairastuneen ohella myös läheiset voivat tarvita tukea oman hyvinvointinsa ja jaksamisensa ylläpitämiseen - usein jo sairauden varhaisessa vaiheessa (Boots ym. 2015), ja sairauden edetessä vieläkin todennäköisemmin (Lethin ym. 2016).

Yksilöllisesti räätälöidylle tuelle on todettu olevan tarvetta kaikissa sairauden vaiheissa (Zwaanswijk ym. 2013; Wu ym. 2018), joskin tuen tarpeita voi olla vaikea määritellä. Muistisairasta hoivaavien läheisten tarpeiden on havaittu olevan monimutkaisia ja vaikeita ulkopuolisenkaan henkilön arvioida. Etenkin puolisohoivaajilla on vaikeuksia nimetä itsekään omia tuen tarpeitaan (Tatangelo ym. 2018). Sairauden vaihe tai läheisen mitattu kuormittuneisuus eivät välttämättä kerro hoivaajien kokemista tuen tarpeista (Stirling ym. 2010). Erään tutkimuksen mukaan puolisoaan hoitavat vaimot olivat kuormittuneempia kuin miehet, vaikka miehet hoitivat vaikeammassa sairauden vaiheessa olevia puolisoitaan (Pöysti ym. 2012).

Suomessa ei ole tehty tutkimusta muistisairaiden läheisten tarpeiden mittaamisesta. Kansainvälinen kirjallisuuskatsaus (Bangerter ym. 2019) osoittaa, että sairastuneen henkilön tarpeiden mittaamiseen on kyllä kehitetty mittareita, mutta läheisten tarpeiden mittaamiseen ei ole yhtenäisiä ja luotettavia mittareita. Läheisten tarpeiden tunnistaminen olisi kuitenkin tärkeää,jotta he voisivat saada oikeanlaista tukea oikeaan aikaan (Sosiaali- ja terveysministeriö 2012; Lethin ym. 2016). Riskinä on läheisten väsyminen. Aiemmat tutkimukset osoittavat muistisairaiden läheisten katuneen, etteivät olleet käyttäneet palveluita jo aiemmin sairauden aikana (Boots ym. 2015; Stephan ym. 2018). Näyttöä on siitä, että palvelut voivat tukea läheisiä monin tavoin.

Muistisairaiden läheisten on todettu hyötyvän erityisesti psykososiaalista tukea tarjoavista palveluista, kuten vertaistuesta tai yksilö- ja ryhmätukea sekä tietoa tarjoavista interven- 
tioista (Parker ym. 2008; McCabe ym. 2016). Vuorohoito on todettu erääksi tärkeimmistä keinoista tukea omaishoitajien jaksamista; se myös jatkaa sairastuneen mahdollisuutta asua kotona (Parker ym. 2008; Vecchio ym. 2018).

Erään kirjallisuuskatsauksen mukaan yksilöllisellä sopivien palveluiden löytymiseen tähtäävällä palveluohjausmallilla pystyttiin merkittävästi tukemaan läheistä ja vähentämään sairastuneen riskiä pitkäaikaishoitoon siirtymiseen (Tam-Tham ym. 2013). Palveluohjauksesta ja nimetystä yhteyshenkilöstä on saatu muutakin positiivista näyttöä merkityksellisinä tekijöinä läheisten tukemisessa (Reilly ym. 2015; Stephan ym. 2018). Hyödyistä huolimatta läheiset kokevat avun hakemisessa ja vastaanottamisessa olevan monia haasteita.

\section{Esteet palveluiden käytölle}

Muistisairaiden läheisillä on täyttämättömiä tuen tarpeita, eivätkä he välttämättä käytä saatavilla olevia palveluja (esim. Greenwood \& Smith 2015; Van Aerschot ym. 2021). Heidän on todettu käyttävän jopa vähemmän palveluja kuin somaattisia sairauksia sairastavien läheisten (Phillipson ym. 2014; Vecchio ym. 2016). Eräs merkittävä selitys tähän on muistisairauteen liittyvä leimautumisen pelko (ADI 2019), mutta suurin syy on useiden tutkimusten mukaan tiedon puute (Phillipson ym. 2014; Werner ym. 2014; Stephan ym. 2018).

Muutamien tutkimusten mukaan läheiset eivät havaitusta hoivataakasta huolimatta edes kokeneet palveluja tarpeellisiksi (Brodaty ym. 2005; Wolfs ym. 2010). Hong ja kumppanit (2011) arvioivat tutkimuksessaan, että tiedon puutteeseen kytkeytyi läheisillä ajatus siitä, ettei palveluja tarvita, joten niistä ei tarvita tietoakaan. Toisaalta on havaittu, että läheisten ja etenkin puolisoiden on vaikea tunnistaa ja myöntää tuen ja palveluiden tarpeensa (Boots ym. 2015; Tatangelo ym. 2018).

MacLeodin ja kumppaneiden (2017) haastattelututkimuksessa tunnistettiin kuusi usei- siin tukiin ja palveluihin liittyvää tekijää, jotka selittivät, miksi palveluja ei ollut käytetty. Syyt olivat: vaikeus löytää tietoa asiaankuuluvista palveluista tai tuista, palveluiden huono laatu, epäluottamus palveluihin, palveluiden joustamattomuus, läheisen uskomukset hoivaroolin velvoittavuudesta ja sairastuneen vastahakoisuus palveluja kohtaan. Tutkimukseen osallistui sekä puolisoita että aikuisia lapsia, mutta tuloksissa ei raportoitu eroja vastaajaryhmien välillä.

Hongin ja kumppaneiden (2011) tutkimuksessa havaittiin, että kevyemmän tuen tarpeessa olevilla oli enemmän estäviä tekijöitä palveluiden käytölle kuin niillä, jotka jo käyttivät useita palveluja. Kynnys palveluiden käyttöön voi siis madaltua, kun käytössä olevien palveluiden määrä kasvaa. Toisaalta monimutkainen palvelujärjestelmä voi myös vaikeuttaa palveluihin hakeutumista. Erään tutkimuksen mukaan läheiset pitivät tiedon ja palveluiden etsimistä jopa vaikeampana kuin itse hoivaamista (Peel \& Harding 2014).

Suomessa ei ole tutkittu erityisesti muistisairaiden henkilöiden läheisten syitä olla käyttämättä palveluja. Aikaisempi kotimainen tutkimus on koskenut yleensä puolisoaan hoitavia omaishoitajia (esim. Kirsi 2004; Turjamaa ym. 2020). Kansainvälisissä tutkimuksissa läheiset taas on yleensä määritelty yhtenäiseksi joukoksi eikä puolisoiden ja aikuisten lasten eroja hoivaajina ole vertailtu (Tatangelo ym. 2018). Sama koskee palveluiden käytön esteitä koskevaa tutkimusta. Aikuisia lapsia vanhempiensa hoivaajina ylipäätään ei ole juuri tutkittu (vrt. Jolanki 2015; Kauppinen \& Silfver-Kuhalampi 2015). Suurin osa aiheeseen liittyvistä kansainvälisistä tutkimuksista on tehty länsimaissa, joissa palvelujärjestelmät ja ihmisten sosiokulttuuriset toimintatavat voivat merkittävästi poiketa eri maissa, joten tulosten vertailu on haastavaa.

Greenwood ja Smith (2015) tekivät kirjallisuuskatsauksen muistisairasta puolisoaan hoivaavien miesten syistä olla käyttämättä palveluja. Tutkimuksia löytyi vain yhdeksän, ja nekin oli tehty pääosin Yhdysvalloissa ennen 
2010-lukua. Tulosten mukaan miesten syyt palvelujen käyttämättömyyteen olivat samansuuntaiset kuin naisilla. Miehet kokivat hoivan velvollisuutenaan ja olivat sitoutuneita tehtäväänsä, mutta heillä oli myös ristiriitaisia tunteita avun hakemista kohtaan. Lisäksi tulokset viittasivat siihen, että miehet hakevat naisia epätodennäköisemmin apua.

Useissa omaishoidontukea koskevissa selvityksissä on todettu muun muassa, että joka toinen omaishoitaja ei käytä lakisääteisiä vapaapäiviään (esim. Leppäaho ym. 2019, 29). Syiden tutkiminen on kuitenkin jäänyt vähälle huomiolle. Palveluiden käyttöä estävien syiden tunnistamista ja poistamista voidaan pitää merkittävänä yhteiskuntapoliittisena kysymyksenä muistisairasta läheistään hoivaavien jaksamisen näkökulmasta. Kansallista tutkimusta tarvitaan, jotta voidaan ymmärtää ja tukea muistisairaita hoivaavia läheisiä ja kehittää heidän tarpeitaan vastaavia palveluja.

\section{Aineisto}

Tutkimuksessa käytetty aineisto on osa laajempaa väitöskirjatutkimusta. Osallistujat $(n=45)$ rekrytoitiin yhteistyössä valtakunnallisen muistiluotsiasiantuntija- ja tukiverkoston kanssa. Verkosto koostuu itsenäisistä Sosiaali- ja terveysjärjestöjen avustuskeskuksen (STEA) rahoittamista maakunnallisista keskuksista, joissa työskentelee muistisairaiden ja läheisten ohjaamisen ja tukemisen asiantuntijoita. Osallistujien rekrytointi tapahtui covid-19-pandemian ensimmäisen aallon loppupuolella. Keskusten työntekijöitä pyydettiin välittämään tutkimukseen osallistumispyyntöä etenkin miehille, koska heidän äänensä kuuluu yleensä vähemmän. Haastateltavia rekrytoitiin sähköposti- ja WhatsApp-ryhmien sekä henkilökohtaisten puheluiden kautta. Osallistumispyynnössä tutkimukseen sopivaksi määriteltiin sellainen henkilö, jonka läheinen oli sairastunut muistisairauteen ja jonka kotona asumista tämä oli mahdollistamassa.
Tutkimukseen haastateltiin kaikki suoraan tutkijalle tai keskuksen työntekijälle yhteystietonsa antaneet 45 muistisairaan henkilön puolisoa tai aikuista lasta. Mukana oli henkilöitä kaikista maakunnista kahta pohjoisinta maakuntaa lukuun ottamatta. Haastateltujen taustatietoja on koottu taulukkoon 1. Puolisoista 15 oli miehiä ja 10 naisia, aikuisista lapsista 6 oli poikia ja 14 tyttäriä. Puolisot olivat 59-82-vuotiaita, ja heidän keski-ikänsä oli 73 vuotta. Aikuiset lapset olivat 27-68-vuotiaita, ja heidän keski-ikänsä oli 50 vuotta. Puolisot olivat yhtä lukuun ottamatta eläkkeellä, kun taas aikuisista lapsista yli puolet oli työelämässä. Suurin osa haastatelluista hoivasi Alzheimerin tautiin tai verisuoniperäiseen muistisairauteen sairastunutta läheistään. Puolisot asuivat samassa taloudessa hoidettavan kanssa. Aikuisten lasten vanhemmista suurin osa asui yksin.

Taulukko 1. Tutkimukseen osallistuneiden ja heidän sairastuneiden läheistensä taustatietoja.

\begin{tabular}{|c|c|c|}
\hline & $\begin{array}{c}\text { Puoliso } \\
n=25\end{array}$ & $\begin{array}{c}\text { Aikuinen } \\
\text { lapsi } \\
\mathbf{n}=\mathbf{2 0}\end{array}$ \\
\hline \multicolumn{3}{|l|}{ Ikäryhmä } \\
\hline alle $45 \mathrm{v}$. & 0 & 7 \\
\hline $45-54 \mathrm{v}$. & 0 & 7 \\
\hline $55-64 \mathrm{v}$. & 2 & 3 \\
\hline $65-74 \mathrm{v}$. & 12 & 3 \\
\hline $75-80 \mathrm{v}$. & 8 & o \\
\hline yli 8o v. & 3 & 0 \\
\hline \multicolumn{3}{|l|}{ Asema työmarkkinoilla } \\
\hline Työelämässä & 1 & 11 \\
\hline Eläkkeellä & 24 & 4 \\
\hline Muu & 0 & 5 \\
\hline \multicolumn{3}{|l|}{ Sairastuneen asuminen } \\
\hline Yksin & o & 15 \\
\hline Puolison kanssa & 25 & 5 \\
\hline \multicolumn{3}{|l|}{ Muistisairaus } \\
\hline Alzheimerin tauti & 20 & 16 \\
\hline Verisuoniperäinen muistisairaus & 3 & 2 \\
\hline Sekamuotoinen muistisairaus & 2 & 2 \\
\hline \multicolumn{3}{|l|}{ Omaishoidontuki } \\
\hline Sopimusomaishoitaja & 20 & 2 \\
\hline Ei virallista omaishoitajuutta & 5 & 18 \\
\hline
\end{tabular}




\section{Menetelmät}

Haastattelut toteutettiin puhelimitse elo-syyskuussa 2020. Ennen varsinaista haastattelua soitettiin ennakoiva puhelu, jossa sovittiin haastatteluaika, kerrottiin haastattelun kulusta ja sovittiin tietoturvatiedotteen lähettämisestä. Ennakkopuhelut olivat tärkeitä myös välittömän ja luontevan tunnelman luomiseksi (vrt. Puusa 2020). Varsinaisen haastattelun alussa pyydettiin suostumus tiedotteen mukaiseen henkilötietojen käsittelyyn ja lupa haastattelun nauhoittamiseen sekä varmistettiin osallistumisen vapaaehtoisuus. Tutkimus ei sensitiivisyydestään huolimatta täyttänyt yhtään kuudesta kriteeristä, jotka olisivat edellyttäneet eettistä ennakkoarviointia. Sekä aineiston keräämisessä että sen käsittelyssä ja hallinnassa on noudatettu hyvän tieteellisen tutkimuksen periaatteita ja ohjeita.

Päätökseen toteuttaa haastattelut puhelimitse vaikuttivat tutkijan aiempi myönteinen kokemus muistisairaiden tukityöstä puhelimitse ja covid-19-pandemia. Puhelinhaastatteluiden on myös arvioitu hälventävän tutkijan ja tutkittavan välisiä valta-asemaan ja ikään liittyviä eroja (Ikonen 2017). Osallistuneet pitivätkin puheluita "mukavina" ja luontevina. Erityisesti puolisot kiittelivät mahdollisuutta osallistua haastatteluun ja sovittaa haastatteluaika esimerkiksi sairastuneen päiväunien ajalle. Helppoa osallistumista ja mahdollisuutta aikataulujen sovittamiseen onkin pidetty puhelinhaastatteluiden etuna (Ikonen 2017).

Haastattelut olivat puolistrukturoituja teemahaastatteluita. Teemat perustuivat aiempaan tutkimukseen ja koko väitöskirjaa koskeviin tutkimuskysymyksiin. Neljä pääteemaa käsittelivät läheisen ja sairastuneen välistä suhdetta, sairastuneen arkea ja läheisen roolia sairastuneen elämässä, kokemuksia tuen ja palveluiden tarpeista ja niiden hakemisesta ja saamisesta sekä läheisen hyvinvointia ja tulevaisuudennäkymiä. Haastattelut eivät edenneet täsmällisesti teemojen mukaisesti, vaan niiden välillä liikuttiin sen mukaan kuin haastateltavat itse toivat niitä esiin (Puusa 2020). Tarkoituksena oli kartoittaa läheisiään hoivaavien tuen ja palveluiden tarpeita sekä sitä, miten saatu apu ja tuki vastasivat niihin. Syyt palveluiden käyttämättä jättämiselle nousivat esille useissa eri kohdissa kysyttäessä erilaisten julkisten ja yksityisten palveluiden käytöstä sekä kolmannen sektorin järjestämään toimintaan osallistumisesta.

Varsinaisten haastatteluiden nauhoitetun osuuden kesto oli keskimäärin yksi tunti. Laaja aineisto litteroitiin sanasta sanaan tekstiaineistoksi. Aineiston analyysi aloitettiin jo litteroinnin aikana tekemällä muistiinpanoja keskeisistä tutkimuskysymyksiin liittyvistä havainnoista. Analyysi jatkui aineiston huolellisella lukemisella. Lukukertojen aikana tehtiin käsitekartta, jossa hahmottuivat aineiston keskeisen sisällön kokonaisuus ja asioiden väliset yhteydet. Aineisto koodattiin Atlas.ti-ohjelman avulla koko tutkimuksen tutkimuskysymysten ja -kirjallisuuden pohjalta luodun koodiston pohjalta. Koodistoa täydennettiin aineistosta johdetuilla koodeilla (Silvasti 2014, 40, 43). Palveluiden käyttöä koskeva tutkimuskysymys tarkentui analyysin aikana palveluiden käyttöä estäviin syihin, kun "palveluiden käytön esteet" havaittiin eniten käytetyksi koodiksi. Aineisto luettiin vielä kerran tämän osatutkimuksen näkökulmasta koodeja täydentäen.

Estäviin tekijöihin liittyvät sitaattikatkelmat siirrettiin taulukkoon haastateltavittain ja vastaajaryhmittäin. Tutkimusaineisto analysoitiin teoriaohjaavan sisällönanalyysin menetelmin, kun sitaattien sisältöjä tarkasteltiin suhteessa aiemmassa tutkimuksessa havaittuihin palveluiden käyttöä estäviin syihin. Analyysiä jatkettiin vertailemalla lainauksien mäariä, eroja ja yhdistäviä tekijöitä vastaajaryhmittäin (vrt. Salo 2015). Sisällöistä muodostettiin viisi kategoriaa, jotka tiivistyivät tuloksia kirjoitettaessa kolmeen pääteemaan niitä yhdistävien lähtökohtien perusteella. Vastaajaryhmien välisiä eroja kuvataan tulososiossa kunkin teeman alla erikseen. 
Tässä osatutkimuksessa analysoitiin kaikki 45 haastattelua. Kuudessa niistä ei kuitenkaan ollut selkeitä kuvauksia palveluiden käytön esteistä. Nämä olivat yhden puolisoaan hoitavan miehen ja viiden tyttären haastattelut. Nämä haastatellut kertoivat saavansa riittävästi tukea ja palvelua eri tahoilta. Lisäksi on huomioitava, että osaan haastatteluista sisältyi kuvauksia lähipiiriltä saatavasta tuesta. Joissakin tapauksissa se todennäköisesti vähensi tarvetta palveluille (vrt. Heikkilä ym. 2020) ja siten myös niihin liittyvää puhetta haastatteluissa.

\section{Tulokset}

Tulosten kolme pääteemaa on jaoteltu sen mukaan, mihin syyt olla käyttämättä palveluja perustuvat. Eniten haastatteluista tunnistettiin muistisairauteen sairastuneen vastahakoisuuteen liittyviä syitä; niistä kertoivat sekä puolisot että aikuiset lapset. Toinen teema muodostuu läheisten kokemuksesta, että palvelujärjestelmä ei vastaa heidän tarpeisiinsa. Aikuiset lapset kuvasivat palvelujärjestelmään liittyviä syitä harvemmin kuin puolisohoivaajat. Kolmas teema koostuu puolisohoivaajien tunteista ja asenteista, jotka muodostivat esteen palvelujen käyttämiselle. Keskeiset tulokset on kuvattu taulukossa 2.

Kaiken kaikkiaan puolisoiden puheesta tunnistettiin merkittävästi enemmän syitä palveluiden käyttämättä jättämiselle kuin aikuisten lasten haastatteluista. Pääteemat eivät olleet toisiaan poissulkevia, ja jotkut haastatellut toivat esille useita syitä siihen, että eivät käyttä- neet palveluja. Etenkin puolisohoivaajilla palveluiden hyödyntämistä estäviä syitä käsittelevät teemat nivoutuivat toisiinsa, ja esimerkiksi sairastuneen haluttomuus palveluiden hankintaan saattoi olla myös hoivaavan puolison mielestä hyvä syy olla hankkimatta lisäapua. Suhteellisesti eniten syitä olla käyttämättä palveluja havaittiin miespuolisoiden puheesta ja vähiten aikuisten poikien puheesta.

Tuloksia vahvistavissa esimerkeissä käytetään seuraavassa pääosin suoria lainauksia haastateltavien puheesta. Lainauksien luettavuutta on hieman helpotettu poistamalla toistoa tai täytesanoja. Aineistoon viittaavat lausumat on nimetty siten, että niistä voi erottaa sairastuneen ja läheisen välisen suhteen, sukupuolen ja iän. Samanikäiset ja sairastuneeseen samassa suhteessa olevat haastatellut on erotettu toisistaan kirjaimella. Esimerkiksi merkintä "Vaimo 69C" tarkoittaa yhtä tutkimukseen osallistunutta 69-vuotiasta vaimoa (joita oli yhteensä kolme).

\section{Sairastuneen vastahakoisuus}

Muistisairauteen sairastuneella voi olla heikentynyt kyky käsittää sairautensa oireet ja niiden vaikutukset läheiseen (Juva 2014), mikä näkyy selvästi tämän tutkimuksen tuloksissa. Haastateltujen läheisten mukaan tärkein syy palvelujen käyttämättömyyteen oli sairastuneen haluttomuus ottaa vastaan palveluja kotiin tai lähteä kodin ulkopuolella oleviin palveluihin. Tämä oli myös keskeisin puolisohoivaajia ja aikuisia lapsia yhdistävä syy.

Taulukko 2. Keskeiset tulokset pääteemoittain.

\begin{tabular}{|l|l|l|}
\hline Sairastunut & Palvelujärjestelmä & Läheinen (puolisohoivaaja) \\
\hline $\begin{array}{l}\text { Ei halua keskustella } \\
\text { palveluista / ottaa palveluita vastaan }\end{array}$ & $\begin{array}{l}\text { Palveluja ei saatavilla } \\
\text { (riittävästi) }\end{array}$ & Vahva tunneside \\
\hline $\begin{array}{l}\text { Ei halua poistua kotoa / } \\
\text { lähteä kodin ulkopuolisiin } \\
\text { palveluihin }\end{array}$ & $\begin{array}{l}\text { Palvelua tarjolla vain } \\
\text { palveluntarjoajan } \\
\text { määrittelemänä ajankohtana }\end{array}$ & (Pärjäämisen) asenne \\
\hline $\begin{array}{l}\text { Estää läheistä hankkimasta } \\
\text { palveluja }\end{array}$ & Palvelu ei vastaa odotuksia & Muita yksittäisiä syitä \\
\hline
\end{tabular}


Läheiset kertoivat, että sairastuneen vastahakoisuus kävi ilmi, kun yritettiin keskustella asioista: palveluihin liittyvistä asioista oli toisinaan vaikea ylipäätään puhua, koska sairastunut ei suostunut keskustelemaan niistä tai suuttui niistä puhuttaessa. Sairastuneet saattoivat lisäksi olla haluttomia osallistumaan yksin tai läheisensä kanssa minkäänlaiseen aktivoivaan, esimerkiksi muistiyhdistyksen järjestämään toimintaan. Jos kotoa lähteminen onnistui, kynnys osallistua jonkinlaiseen toimintaan madaltui.

Äärimmäisissä tapauksissa läheiset eivät saaneet sairastunutta poistumaan kotoaan edes kaupassakäynnin tai kyläilyn vuoksi. Näissä tilanteissa aikuiset lapset olivat erityisesti huolissaan vanhempansa elämänlaadusta ja riittävän hoivan turvaamisesta.

\section{Äiti ei suostu menemään minnekään. Että kun} bän ei poistu sieltä kotoaan kauppaan ei mibinkään. (Tytär 53)

Puolisohoivaajille sairastuneen vastahakoisuus aiheutti puolestaan sosiaalista eristäytymistä ja sitoi heitä kotiin, mikäli he eivät voineet jättää puolisoaan yksin kotiin tai tämä ei halunnut ottaa edes vieraita vastaan.

\section{Kyllä mä oon ollu niinku vuorokaudet ympä- riinsä tässä näin. Mutta ne on ne vapaat ollu semmoisia enintään parin tunnin keikkoja sit- ten kun on joku muu sitten ollu. (Aviomies 76B)}

Puolisohoivaajien kuvauksissa sairastuneen vastahakoisuus kohdistui erityisesti vuorohoitoon lähtemiseen. Tavallisin tilanne oli, että sairastunut ei halunnut lähteä kodin ulkopuoliseen vuorohoitoon eikä vaihtoehtoja vapaapäivien pitämiseen ollut tarjolla. Osa sairastuneista vastusti myös ajatusta kotiin tulevasta hoitajasta, vaikka sellainen olisi joidenkin ollut mahdollista saada. Näissä tilanteissa hoivaajalla ei ollut mahdollisuutta jaksamisensa kannalta tärkeän vapaa-ajan ja levon saantiin.
No en mä tiïa, sitä ei nyt oo halunnu läbtee vielä laittamaan siinä vaiheessa mihinkään tonne palvelutaloon. Se on tietysti vielä siinä vaiheessa, kun sillä on sitä ommaa ajatusta, niin se on vähän hankala edes laittaakaan. Se pistää hanttiin niin paljon. (Avomies 59)

Sitten kun oli niistä, että kolme vapaapäivää kuukaudessa, niin sitä ruettiin pohtimaan niin hän sano, että hän ei kettää vierasta naista tänne ota eikä bän mibinkään hoitolaitokseen lähe tai sitten hänet saa viedä sinne kokonaan. (Vaimo 69A)

Haastateltavien mukaan sairastuneet saattoivat vastustaa myös yksityisten palveluiden ostamista, vaikka palvelut olisivat liittyneet kodinhoidollisiin tehtäviin. Eräs äitinsä kanssa asuva 67-vuotias tytär kertoi, että äiti oli vihainen hankitusta palvelusta, vaikka hän ei itse enää kyennyt laittamaan ruokaa: meitä on kaks naista täällä, että eikö me nyt saada ruokaa laitettua. Sairastuneen vastahakoisuus yksityisiä palveluja kohtaan tuli esiin sekä aikuisten lasten että puolisoiden haastatteluissa.

Läbinnä siivousta --- että se on niin jännä juttu, että pitää varoa aina sanojaan semmosessa asiassa, missä minä vetoan mieheni kuntoon tai tilanteeseen, niin se ei onnistu. Pitää kierrättää itseni kautta niin sitten se saattaa jopa onnistua. (Vaimo 64)

Toisin kuin puolisot, aikuiset lapset pohtivat vanhemman itsemääräämisoikeuteen liittyviä kysymyksiä palveluja hankittaessa. Osa heistä oli tyytynyt siihen, että vanhemman tahto oli se, ettei palvelua hankita, kun taas toiset olivat vanhemman vastusteluista huolimatta ostaneet palveluja. Puolisoiden oli vaikea hankkia palveluja, jos sairastunut vastusti niitä.

Ei se tykänny siitä siivoojasta, ei siivouksen tuloksesta eikä siivoojasta, ku se jutteli vaan mun kanssa. (Aviomies 76A) 
Mutta kun mä oon jotenkin sillain ajatellu, että tää nyt on sitä mitä ne haluaa. Että oon kertonut näistä ja vähän tuputtanutkin, mutta oon yrittänyt ajatella, että kun vielä isä pystyy vielä asioista päättämään niin pitää nyt kunnioittaa sitä, mitä ne haluaa, kun ei ole tilanne mikään katastrofaalinen, että sitte tietysti, jos näkee, että tästä ei tuu mitään, niin tottakai sitten pitää puuttua. (Tytär 53)

Aikuiset lapset kertoivat myös, että sairastunut vanhempi saattoi estää tai kieltää lapsia hankkimasta apua julkiselta sektorilta. Haastateltavien mukaan he saattoivat kieltäytyä tarjotusta avusta vetoamalla siihen, että pärjäävät vielä itsekin. On mahdollista, että lapselta tai lapsilta saatava apu ja tuki vähensi muun palvelun tarvetta ja että sairastunut vanhempi luotti saavansa heiltä tarvittavaa tukea ja sen takia kieltäytyi muusta ulkopuolisesta palvelusta.

Ei se haluu, että meillä on käynyt kaks kertaa kaupungin muistineuvoja siellä, jotka kauheesti yrittää tarjota semmosta kauppa-apua tai ruoka-apua tai suibkuapua, mutta bän on sitä mieltä, että bän pärjää. (Tytär 50)

\section{Palvelujärjestelmän puutteellisuus}

Palvelujärjestelmään liittyvät syyt olivat vaihtelevia. Tyypillisimmin syy oli se, ettei läheinen kokenut järjestelmän vastaavan hänen kokemaansa avun ja tuen tarpeeseen. Puolisoilla palvelujärjestelmään liittyvät syytkin kytkeytyivät usein vapaa-ajan saamiseen. Koska kuntien palvelutaso vaihtelee, läheiset olivat eriarvoisessa asemassa palveluiden saajina (vrt. Finne-Soveri 2015). Puolisohoivaajat toivoivat, että he olisivat voineet saada kotiin hoitajan tai puolisolle paikan päivätoimintaan. Näitä palveluja ei kuitenkaan heidän asuinkunnissaan ollut saatavilla, vaikka monilla paikkakunnilla esimerkiksi päivätoimintaa on tarjolla (Tommola ym. 2021). Palveluiden käyttöä esti myös se, että niitä tarjottiin "virka-aikana" eli vain arkipäivisin, mikä ei mahdollistanut lähei- sille tärkeiden ja voimavaroja antavien asioiden toteutumista, kuten iltaharrastuksia tai sukujuhliin pääsyä.

Sitten niin meille soitettiin, että perjantaiaamuna me voisimme tulla, mutta minä että voi kiitos, mutta kun minä en perjantaiaamuna tarvitse apua. Että tarvin keskiviikkona, kun menen vesijumppaan ja menen illalla johonkin konserttiin, niin mä tarvin sillon apua, et se on tämmöstä vaibtelevaa... ei he illalla tuu. (Vaimo 69B)

Semmonen tuki olis ainaki, että sais päivän pari viikossa, että olis jossain päivätoiminnassa tai semmosessa jossain, että sais sitte ja sais itekki väbän olla niinku vappaasti. (Vaimo 70A)

Suurin osa puolisoista (20/25) oli sopimusomaishoitajia, joilla on lakisääteinen oikeus omaishoidon tukeen kuuluviin vapaapäiviin. Vapaiden pitämisessä oli kuitenkin ongelmia. Kaksi miehistä kertoi, ettei ollut pystynyt pitämään vapaapäiviä hoitopaikkojen puutteen vuoksi. Hoitopaikka olisi pitänyt varata kuukausia aikaisemmin, jolloin he eivät vielä tienneet omia tulevia menojaan. Lisäksi vapaapäivien pitämistä estivät muutkin asiat. Puolisohoivaajat olivat esimerkiksi kokeneet, että vuorohoidon sisältö tai hoitopaikan olosuhteet eivät vastanneet heidän odotuksiaan. Lisäksi he olivat kokeneet sairastuneen toimintakyvyn heikentyneen vuorohoidon aikana, jolloin siitä palautuminen vaikeutti hoidon jälkeistä arkea. Niinpä he olivat lopettaneet vuorohoidon tai vähentäneet hoitopäivien määrää omasta levon tarpeestaan huolimatta.

Lokakuusta kyselin, niin ei oo paikkoi, niin mullahan jäi yli puolet niistä vapaapäivistä pitämättä. Se on minun mielestä organisaation vika. Eibän se voi mitää se, joka niitä järjestelee se asiakaspalvelusibteeri, jos siellä ei oo paikkoi, niin ei se voi paikaks muuttua. (Aviomies 74) 
Viime syksynä mä laitoin hänet sitten kolmeks vuorokaudeks tämmöseen palvelutaloon. Mutta se oli, se oli niin järkyttävä kokemus, että sen jälkeen mä en oo sitten laittanu. (Aviomies 70B)

Osa puolisoista ja aikuisista lapsista koki palvelujärjestelmän sekavuuden tai henkilöstön vaihtuvuuden hidastavan palveluiden järjestämistä: kun sai soittaa aika moneen paikkaan ja selvittää, että kukas tästä nyt vastaa (Poika 53B). Tämä ei kuitenkaan noussut haastatteluissa merkittäväksi esteeksi palveluiden hakemiselle.

Vertaistuen on useissa tutkimuksissa todettu olevan tärkeä henkisen tuen muoto muistisairaiden läheisille (esim. McCabe 2016). Järjestötoimintaan osallistuneet puolisohoivaajat olivat tyytyväisiä saamaansa vertaistukeen ja muilta muistisairaiden läheisiltä saamiinsa neuvoihin. Sen sijaan aikuisilla lapsilla oli kokemuksia siitä, että yhdistysten toiminta ei vastannut heidän tarpeitaan tai sitä ei tarjottu heille sopivalla aikataululla. Osa haastatelluista aikuisista lapsista olisi myös kaivannut nimenomaan vanhempaansa hoitaville tarkoitettua vertaistukiryhmää erilaisen näkökulman vuoksi.

Mä kävin muistiyhdistyksen vertaistukiryhmässä, niin se ei sitten ihan vastannut siiben tarpeeseen jobtuen läbinnä siitä, että muut osallistujat oli pariskunnan toinen osapuoli. Se keskitty enemmän siihen, että millaista se elämä on, kun se tuttu kumppani ei enää olekaan sellainen, kun hän oli. Mutta siinä ei ollut niin kuin siiben liittyen, että miten se muuttaa elämää, kun sä huolehdit kotona $y k$ sin asuvaa muistisairasta, mutta samalla niin, että sä pyörität ja elät sun omaa arkea toisaalla. (Tytär 43)

\section{Vahva tunneside ja asenne}

Läheiseen itseensä liittyvät syyt olla käyttämättä palveluja koskivat ainoastaan puolisohoivaa- jia; aikuiset lapset eivät kuvanneet vastaavia haasteita. Puolisohoivaajat olivat yhtä lukuun ottamatta eläkkeellä, ja he asuivat samassa taloudessa sairastuneen puolisonsa kanssa. Vaikka puolisot kokivat väsymystä ja tarvetta omalle ajalle, oli puolison vieminen vuorohoitoon vaikeaa ja aiheutti emotionaalisia ristiriitoja (vrt. Tollhurst ym. 2019). Sama koski myös sairastuneen puolison siirtymistä palvelutaloon, mikä oli kahdelle haastatelluista puolisoista ajankohtainen asia. Päätöksen tekeminen oli kipeä ja vaikea asia.

Niin siksi sitä yrittää venyttää siihen viimeseen asti, että mäkin oon kuukausi kerrallaan jo pitkän aikaa tappina menny eteenpäin. Kun se on, sitä ei niin kun haluaisi ajatella, että se on lopullista. Se on vaan näin. (Aviomies 72)

Puolisoiden elämät vaikuttavat monin tavoin toisiinsa (esim. Sointu 2016), ja tässäkin aineistossa puolisohoivaajat saattoivat perustella palveluiden käyttämättä jättämistään toteamalla: ajattelepa omalle kohdalle. Miesten ja vaimojen tavat kuvata tilannetta erosivat toisistaan. Miehet puhuivat mieluummin siitä, etteivät he saaneet aikaiseksi hankkia palvelua, kun taas vaimot sanoivat, etteivät raaskineet tai hennoneet laittaa miestään vuorohoitoon. Eräs vaimo totesi haastattelun aikana useita kertoja, miten vaikeaa miehen laittaminen vuorohoitoon on, kun ollaan oltu melkein 60 vuotta naimisissakin.

Mun miehelle on justiin laitettu, niin että sillä on ens kuukaudeks laitettu niin kun viikko intervallia, mutta niin tuota mua väbän, ei mun oo pakko sitä, ei hän oo koskaan ollu vielä pois yötä. Ei koko aikana missään kotoo pois, niin mä nyt pyörittelen sitä, et tuota niin, niin tätä. Mä väbän katon tätä tilannetta tässä. Mutta (naurahdus) jos tilanne on näin niin kun nyt on, niin en usko, että mä vien. (Vaimo 78) 
Toinen alateema läheiseen liittyvissä syissä oli omin avuin pärjääminen. Monet puolisoista käyttivät nimenomaan sanaa "pärjätä", mutta samasta asiasta puhuttiin myös epäsuoremmin. Puolisot perustelivat pärjäämistään kertomalla, miten kaupasta saa valmiita ruokia ja kodinkoneet pesevät pyykit ja astiat. Puolisot saattoivat verrata nykyistä tilannettaan menneisiin aikoihin kertomalla, miten belppoa nykyään kuitenkin on. Osa myös arveli, että on sellaisia ihmisiä, jotka tarvitsevat palveluja enemmän kuin he.

No, ei oo ollu vielä, mutta niin kun tommosta ikkunanpesua nyt oon miettiny, että pitäskö nyt ottaa jo. Se on hankalin homma tässä tuo ikkunoiden peseminen, kun pitää vääntää riepuja ja rättiä ja se vääntäminen on just mun käsille vähän huonoa. Mutta ite oon nyt oikeesti kaikki hoitanu tässä nää hommat, että ei tässä niin kun. Oon talonmiehenä ja miks$k \ddot{a}$ (naurahdus) yleismies Jantuseks sanois. (Vaimo 70B)

Pitäs vaan yrittää, mikä ei aina oo helppoo ja sit vähän niinku positiivisen kautta, että ajattelis. Jos multa menis sormi poikki, niin se meni, mutta multa olis voinut mennä vaikka käsikin poikki. Että, se on helpommin sanottu ku tehty. Mut kyl me edelleen pärjätään, kun me edelleen tuetaan toisiamme. (Aviomies 74)

Temaattisesti lähellä pärjäämistä oli puhe siitä, ettei tarvetta palveluille koeta olevan. Tällaista puhetta oli erityisesti muutamien miespuolisoiden haastatteluissa, mikä voi kuvata vanhemman sukupolven eetosta yksin pärjäämisestä. Haastatteluiden perusteella on vaikea arvioida, oliko kyse siitä, että läheinen ei tunnistanut eikä myöntänyt avuntarvetta (vrt. Tatangelo ym. 2018) vai siitä, että hän ei aidosti kokenut tarvetta palveluille. Näiden puolisoiden haastatteluissa saattoi kuitenkin käydä ilmi muita seikkoja, jotka todennäköisesti viittasivat lisääntyneeseen tuen tarpeeseen.
Niin. Sanotaan nyt näin, että se on semmosta, että niin ennen teki varttitunnissa sen, mitä nyt siinä menee koko päivä, mutta sehän on tämä elämänkaari tämmönen, että tuota. Siinä on niin kun vähän, että kyllä sitä tulee mieleen, että niin kun sanotaan, että sitä apua tuota esim. tulee nyt mieleen. Mutta tuota oonko minäkin sitten vähän semmonen niin kun, sen luontonen, että minä itse tuota, että eibän sitä muut (naurua). (Avomies 82).

Yksittäisinä mainintoina haastatteluissa tuli esiin muitakin puolisohoivaajien asenteita ja ajatuksia, jotka estävät heitä vastaanottamasta palveluja. Muutama vaimo kuvasi esteeksi sen, että koti on yksityistila, johon on vaikea vastaanottaa palvelua. Eräs puoliso totesi, ettei halunnut ottaa vastaan "sosiaaliapua", ja eräs mies pohti, ettei "työläistaustaisena" ole tottunut ajatukseen ostaa yksityisiä palveluja.

\section{Pohdinta}

Tämän tutkimuksen tarkoituksena oli tuottaa tietoa syistä, joiden takia muistisairauteen sairastuneiden läheiset eli puolisot ja aikuiset lapset eivät käytä palveluja. Tulosten mukaan keskeiset syyt olivat: 1) sairastuneen vastahakoisuus ja estely palveluiden vastaanottamiseen ja hankkimiseen, 2) palveluiden puuttuminen, riittämättömyys, joustamattomuus tai huono laatu ja 3) puolisohoivaajien tunteet ja asenteet. Tutkimus tuo uutta tietoa erityisesti siitä, miten puolisoiden ja aikuisten lasten nimeämät syyt eroavat toisistaan.

Tulokset vahvistavat aiempien tutkimuksien tuloksia siitä, että muistisairaiden läheisillä on monenlaisia syitä olla käyttämättä palveluja. Tulokset olivat samansuuntaiset MacLeodin ja kumppaneiden (2017) tutkimuksessa tunnistettujen syiden kanssa. Edellä mainitun tutkimuksen keskeisin syy, tiedonpuute, ei tässä tutkimuksessa kuitenkaan selkeästi tullut esille; haastateltavien puheessa tiedonpuutteeseen viittaavia mainintoja oli vain muutamia. 
Aikaisemmissa tutkimuksissa on havaittu, että muistisairauteen sairastuneen saama tuki ja läheisen saama tuki kytkeytyvät ja vaikuttavat toisiinsa (Cova ym. 2018). Tämän tutkimuksen tulokset osoittavat, että tämä koskee myös palveluiden käyttämättä jättämisen syitä. Sairastuneen tuntema vastahakoisuus palveluja kohtaan on raportoitu syyksi myös kahdessa aiemmassa tutkimuksessa (Brodaty ym. 2005; MacLeod ym. 2017). Tässä tutkimuksessa sairastuneen vastahakoisuus oli sekä puolisoiden että aikuisten lasten mukaan keskeisin syy olla käyttämättä palveluja. Sairastunut voi arvioida virheellisesti oman fyysisen ja kognitiivisen toimintakykynsä, minkä lisäksi hänellä voi olla pelkoja ja väärinkäsityksiä, jotka aiheuttavat vastahakoisuutta (Eggenberger ym. 2013). Toisaalta muistisairaat ovat itsekin ilmaisseet halunsa säilyttää itsenäisyytensä ja vaikuttaa heitä koskeviin palveluihin niin kauan kuin se on mahdollista (Stephan ym. 2018).

Sairastuneen vastahakoisuus ottaa vastaan palvelua lisää puolisoilta ja aikuisilta lapsilta tarvittavan tuen ja avun tarvetta. Sairastuneen aloite- ja toimintakyvyn heikkenemisen takia myös kodinhoito jää todennäköisesti läheisen tehtäväksi. Näin läheisen vastuu lisääntyy ja voi aiheuttaa väsymystä. Aikuiset lapset joutuvat tasapainottelemaan vanhemman hoivaamisen ja muun elämän velvollisuuksien hoitamisen välillä. Lisäksi he kantavat huolta sairastuneen vanhempansa tilanteesta ja riittävästä hoivasta silloinkin, kun eivät ole hänen luonaan (vrt. Sointu 2011). Aiemmassa tutkimuksessa on todettu, että sairastuneen saama palvelu vähentää läheisten vastuuta sairastuneesta (Heikkilä ym. 2020). Sairastuneen vastahakoisuus palveluja kohtaan vaikuttaa kuitenkin enemmän puolisoihin kuin aikuisiin lapsiin.

Sairastuneen haluttomuus poistua kotoa tai osallistua mihinkään toimintaan rajoittaa merkittävästi myös puolison sosiaalista elämää. Tämä on havaittu muissakin puolisohoivaa koskevissa tutkimuksissa (Kauppinen \& Silfver-Kuhalampi 2015, 52). Lisäksi sairastuneen haluttomuus vuorohoitoon estää puoliso- hoivaajia saamasta lepoa ja taukoa hoivasta, mikä olisi jaksamisen kannalta tärkeää. Sama havainto tehtiin myös Turjamaan ja kumppaneiden (2020) tutkimuksessa.

Puolisohoivaajien kokemusten mukaan lepoa tarjoavat palvelut eivät olleet riittäviä, laadukkaita tai oikea-aikaisia. Vuorohoitoon liittyviä ongelmia on raportoitu myös useissa aiemmissa tutkimuksissa (esim. Sointu 2016; Van Aerschot ym. 2021), joten niiden kehittämiseen tulisi kiinnittää erityistä huomiota. Läheisten jaksamisen kannalta vapaa-ajan ja levon turvaaminen on keskeinen asia. Näiden palveluiden saatavuus ja laatu eivät ole kuitenkaan kehittyneet viime aikoina muiden muistisairaille ja heidän läheisilleen tarkoitettujen palveluiden tavoin (Tommola ym. 2021), ja tarjolla olevat palvelut vaihtelevat kunnittain (FinneSoveri 2015). Läheisten eriarvoisuus palvelunsaajina näkyi tutkimuksen tuloksissa: samaa palvelua oli toisaalla tarjolla, toisaalla taas ei. Myös MacLeodin ja kumppaneiden (2017) tutkimuksessa havaittiin useita palvelujärjestelmään liittyviä palveluiden käyttöä estäviä syitä: läheisillä oli epäluottamusta palveluihin tai he pitivät niitä huonolaatuisina tai joustamattomina. Mainitussa tutkimuksessa ei kuitenkaan havaittu syyksi sitä, että palveluja ei olisi ollut saatavilla tai että ne olisivat olleet riittämättömiä. Tässä tutkimuksessa palvelujärjestelmään liittyvät ongelmat koskivat niin julkisia, yksityisiä kuin kolmannenkin sektorin palveluita.

Palvelujärjestelmään liittyvien ongelmien on todettu ennustavan muistisairaan kotona asumisen päättymistä (Hartikainen ym. 2008, 108). Osa tähän tutkimukseen haastatelluista läheisistä piti palvelujärjestelmää monimutkaisena ja henkilöstön vaihtuvuutta ongelmana; se kuitenkin vain hidasti palveluiden hankkimista muodostamatta varsinaista estettä palveluiden saamiselle, kuten aiemmissa tutkimuksissa on todettu (Hong ym. 2011; Peel \& Harding 2014). Koska tutkimukseen oli saattanut valikoitua keskimääräistä aktiivisempia kansalaisia, tähän tulokseen on syytä suhtautua varauksella. 
Sairastuneen henkilön omat ja puolison syyt olla käyttämättä palveluja nivoutuivat usein toisiinsa tiiviisti. Aikuisten lasten kohdalla näin tapahtui harvemmin. Sairastuneen vastahakoisuuden ja vuorohoidon ongelmien lisäksi puolisohoivaajat kokivat ajatuksen sairastuneen puolison viemisestä hoitoon emotionaalisesti vaikeaksi. Useissa aiemmissa tutkimuksissa on havaittu, että puolisohoivaajilla on vahva tunneside hoidettavaan ja hoiva nivoutuu vahvasti keskinäiseen suhteeseen (esim. Sointu 2016, 223).

Puolisoiden ja aikuisten lasten erilaista suhtautumisessa palveluihin voi selittää myös sukupolvien välinen ero palveluiden käyttäjinä. Aikuiset lapset ovat kasvaneet hyvinvointipalveluja rakennettaessa ja ovat tottuneempia käyttämään palveluja, kun taas vanhemmat sukupolvet ovat tottuneet "pärjäämään" ilman niitä. Lisäksi aiemmissa tutkimuksissa on havaittu, että puolisoiden on aikuisia lapsia vaikeampaa tunnistaa omia tarpeitaan (Tatangelo ym. 2018) tai hyväksyä niitä (Boots ym. 2015). Puolisohoivaajat tarvitsevatkin rohkaisua palveluiden käyttöön.

Toisin kuin varhaisemmat tutkimukset (Brodaty ym. 2005; Phillipson ym. 2014) tämä tutkimus ei vahvistanut sairauteen liittyvän leimautumisen pelon tai tiedon puutteen olevan syy palvelujen käyttämättömyyteen. Muistisairauksista puhutaan julkisuudessa yhä enemmän, mikä on saattanut vähentää sairauteen liittyvää häpeää ja lisätä tietoisuutta palveluista. Lisäksi tietoa on saatavilla internetistä, jota yhä vanhemmat ikäpolvet käyttävät. Tilastokeskuksen (2020) tietojen mukaan 65-74-vuotiaista jo 88 prosenttia käyttää internetiä. Suurin osa tutkimukseen osallistujista oli alle 80-vuotiaita, mikä voi selittää heidän valmiuksiaan etsiä tietoa. Yhtä lukuun ottamatta kaikilla haastateltavilla olikin sähköpostiosoite tietosuojaselosteen lähettämistä varten. On myös mahdollista, että osallistujat olivat saaneet järjestötoiminnan kautta tietoa erilaisista tuista ja palveluista, vaikka kaikki haastatellut eivät osallistuneet järjestöjen toimintaan.
Tutkimukseen liittyy rajoitteita, jotka on syytä ottaa huomioon. Tutkimukseen haettiin osallistujia muistiyhdistysten kautta, joten on mahdollista, että haastatellut edustavat keskimääräistä aktiivisempia tuen ja avun hakijoita. Siksi heillä voi olla keskimääräistä vähemmän syitä olla hakematta tukea ja palveluja. Tutkimukseen osallistuneiden läheiset sairastivat joko Alzheimerin tautia tai verisuoniperäisiä muistisairauksia. Nämä ovat toki yleisimmät muistisairaudet (Muistisairaudet: Käypä hoito -suositus 2020), mutta tulokset eivät välttämättä ole yleistettävissä muita muistisairauksia sairastavien läheisten kokemiin syihin. Aikuisten lasten ja puolisohoivaajien erot tuloksissa olivat selkeät, mutta sukupuolten välisistä eroista tarvittaisiin lisätutkimuksia. Puolisohoivaajista miesten ja vaimojen esteet olivat keskenään jokseenkin samanlaisia; miehillä syitä havaittiin kuitenkin suhteellisesti enemmän. Vähiten syitä tunnistettiin aikuisilla pojilla.

Tutkimuksen vahvuutena voidaan pitää sitä, että haasteltavia oli lähes kaikista maakunnista. Lisäksi puhelinhaastattelu aineiston keruumenetelmänä mahdollisti myös sellaisten puolisoiden osallistumisen tutkimukseen, jotka sitovan omaishoitosuhteen vuoksi olisivat voineet muutoin jäädä tutkimuksen ulkopuolelle. Toisaalta tuloksia arvioitaessa on syytä huomioida, että mikäli tutkimukseen osallistuneilla oli tavanomaista paremmat valmiudet tuen ja palveluiden hakemiseen ja vastaanottamiseen, todellisuus muistisairaiden läheisten kokemista syistä on jopa karumpi kuin tulokset osoittavat.

\section{Johtopäätökset}

Ikääntyvän Suomen näkökulmasta läheisten jaksamisen tukeminen on avainasemassa kotona asumisen mahdollistamisessa. Etenkin muistisairaita hoitavilla puolisoilla on erityinen riski jäädä ilman tarvitsemiaan palveluja. Muistisairaat ja heidän läheisensä tarvitsevat tukea palveluiden käyttämistä estävien syiden 
poistamiseen ja saatavilla olevien palveluiden käyttöön. Lisäksi heille kohdistettua palvelujärjestelmää tulisi kehittää niin, että palvelut vastaisivat läheisten tarpeisiin tasa-arvoisemmin eri puolilla Suomea.

Palveluiden kehittäminen on olennaista, mutta läheisten tukeminen on moniulotteisempi teema. Kotona asuvien muistisairaiden ja heidän läheistensä tukeminen voi olla haastavaa, jos sairastunut ei itse halua ottaa tukea ja palvelua vastaan. Aiemmin on todettu, että kouluttamalla ammattilaisia ja läheisiä vuorovaikutukseen sairastuneen kanssa voidaan lievittää sairastuneen vastahakoisuutta ja vahvistaa läheisen ja sairastuneen välistä suhdetta (Eggenberger ym. 2013). Koulutus voitaisiin liittää esimerkiksi osaksi omaishoitajien lakisääteistä koulutusta, ja sen järjestämisessä voitaisiin hyödyntää muistijärjestöjen osaamista.

Luotettava palveluohjaaja, joka tuntee sairastuneen ja hänen läheisensä, voisi sairauden edetessä kannustaa sairastunutta ja läheistä vastaanottamaan heille sopivaa tukea (vrt. myös Stephan ym. 2018). Tämä olisi tärkeää

\section{Kirjallisuus}

ADI. World Alzheimer report 2019: attitudes to dementia. London: Alzheimer's Disease International. Internet: https://www.alzint.org/u/ WorldAlzheimerReport2019.pdf (viitattu 12.3.2021).

Bangerter L, Griffin J, Zarit S, Havyer R. Measuring the needs of family caregivers of people with dementia: an assessment of current methodological strategies and key recommendations. J Appl Gerontol 2019;38(9):1304-18. https://doi.org/10.1177/0733464817705959

Boots L, Wolfs C, Verhey F, Kempen G, De Vugt M. Qualitative study on needs and wishes of early-stage dementia caregivers: the paradox between needing and accepting help. Int Psychogeriatr 2015;27(6):927-36. https://doi.org/10.1017/S1041610214002804

Brodaty H, Thomson C, Thompson C, Fine M. Why caregivers of people with dementia and memory loss don't use services. Int J Geriatr Psychiatry myös läheisille, kuten tämäkin tutkimus osoitti. Sosiaalipalveluiden lähtökohtana on kunnioittaa ja edistää asiakkaan oikeutta tehdä omia valintoja (Karvonen-Kälkäjä 2012, 238), mutta muistisairaan henkilön valinnat kytkeytyvät myös häntä hoivaavan läheisen oikeuksiin ja tarpeisiin. Muistisairauteen sairastuneiden henkilöiden läheisten jaksamiseen ja heidän palvelutarpeidensa selvittämiseen ja mittaamiseen tulisikin kiinnittää erityistä huomioita.

\section{Kiitokset}

Osoitan lämpimät kiitokseni tutkimustyöni mahdollistaneille rahoittajille: OLVI-Säätiölle ja Alli Paasikiven Säätiölle.

\section{Yhteydenotto:}

Ulla Halonen, YTM, väitöskirjatutkija

Yhteiskuntatieteiden ja filosofian laitos

Jyväskylän yliopisto

ulla.m.halonen@student.jyu.fi
2005;20(6):537-46.

https://doi.org/10.1002/gps.1322

Chiao C, Wu H, Hsiao C. Caregiver burden for informal caregivers of patients with dementia: a systematic review. Int Nurs Rev 2015;62(3):34050. https://doi.org/10.1111/inr.12194

Connors M, Seeher K, Teixeira-Pinto A, Woodward M, Ames D, Brodaty H. Dementia and caregiver burden: a three-year longitudinal study. Int J Geriatr Psychiatry 2020;35(2):250-8. https://doi.org/10.1002/gps.5244

Cova I, Travi N, Maggiore L, Cucumo V, Mariani C, Pomati S. What are the caregivers' needs on dementia care? An integrated qualitative and quantitative assessment. Neurol Sci 2018;39(6):108591.https://doi.org/10.1007/s10072-018-3332-3

Eggenberger E, Heimerl K, Bennett M. Communication skills training in dementia care: a systematic review of effectiveness, training content, and didactic methods in different care settings. Int 
Psychogeriatr 2013;25(3):345-58. https://doi.org/10.1017/S1041610212001664

Finne-Soveri H. Kansallisen muistiohjelman toimeenpanosuunnitelma vuosille 2015-2020. Helsinki: THL, 2015. http://urn.fi/URN:ISBN:978-952-302-594-3

Greenwood N, Smith R. Barriers and facilitators for male carers in accessing formal and informal support: a systematic review. Maturitas 2015;82(2):162-9. https://doi.org/10.1016/j.maturitas.2015.07.013

Halonen U, Van Aerschot L, Oinas T. Palveluohjaus määrittää muistisairaan läheisten palvelujen saamista - aikuiset lapset puolisoita heikommassa asemassa. Janus 2021;29(2):103-21. https://doi.org/10.30668/janus.87771

Hartikainen S, Lönnroos E, Rusanen S, toim. Geriatria: Arvioinnista kuntoutukseen. Helsinki: Edita, 2008.

Heikkilä R, Mäkelä M, Noro A, Lammintakanen J, Laulainen S. Millaisilla palveluilla enintään keskivaikeasti oireilevat muistisairautta sairastavat henkilöt pärjäävät kotona? Gerontologia 2020;34(2):74-87.

https://doi.org/10.23989/gerontologia.84723

Hong S, Hasche, Lee M. Service use barriers differentiating care-givers' service use patterns. Ageing Soc 2011;31(8):1307-29. https://doi.org/10.1017/S0144686X10001418

Ikonen HM. Puhelinhaastattelu. Teoksessa: Hyvärinen M, Nikander P, Ruusuvuori J, toim. Tutkimushaastattelun käsikirja. Tampere: Vastapaino 2017:270-84.

Jolanki O. Elderly parents' need for help and adult children's moving decisions. J Hous Elderly 2015;29(1-2):77-91. https://doi.org/10.1080/02763893.2015.989763

Juva K. Alkava muistisairaus - milloin muistihuoli ohjaa kattaviin tutkimuksiin? Duodecim, 2014;130(10):969-74. Internet: https://www. duodecimlehti.fi/duo11656 (viitattu 13.3.2021).

Karvonen-Kälkäjä A. Unohtuuko vanhus? Oikeustieteellinen tutkimus hallintosopimuksen asianosaissuhteista vanhuksen vaikuttamismahdollisuuden näkökulmasta. Helsinki: Vanhustyön keskusliitto, 2012. Internet: https://vtkl.fi/ wp-content/uploads/2019/07/Unohtuuko_vanhus.pdf (viitattu 5.5.2021).

Kauppinen K, Silfver-Kuhalampi M. Työssäkäynti ja läheis- ja omaishoiva - työssä jaksamisen ja jatkamisen tukeminen. Helsingin yliopisto, Sosiaali- tieteiden laitos, 2015.

https://hdl.handle.net/10138/158347

Kirsi T. Rakasta, kärsi ja kirjoita:Tutkimus dementoitunutta puolisoaan hoitaneiden naisten ja miesten hoitokokemuksesta. Acta Electronica Universitatit Tamperensis 399. Tampere: Tampereen yliopisto, 2004.

https://urn.fi/urn:isbn:951-44-6152-5

Kröger T, Yeandle S. Reconciling work and care: an international analysis. In: Kröger T, Yeandle $\mathrm{S}$, ed. Combining paid work and family care. Policy Press, 2013:3-22.

Leppäaho S, Kehusmaa S, Jokinen S, Luomala O, Luoma M. Omais- ja perhehoidon kehitys vuosina 2015-2018: Päätelmät ja suositukset jatkotoimenpiteiksi. Helsinki: Sosiaali- ja terveysministeriö, 2019:25-36.

http://urn.fi/URN:ISBN:978-952-00-4022-2

Lethin C, Hallberg I, Karlsson S, Janlöv A. Family caregivers experiences of formal care when caring for persons with dementia through the process of the disease. Scand J Caring Sci 2016;30(3):52634. https://doi.org/10.1111/scs.12275

Macleod A,Tatangelo G, McCabe M, You E. "There isn't an easy way of finding the help that's available." Barriers and facilitators of service use among dementia family caregivers: a qualitative study. Int Psychogeriatr 2017;29(5):765-75. https://doi.org/10.1017/S1041610216002532

McCabe M, You E, Tatangelo G. Hearing their voice: a systematic review of dementia family caregivers' needs. Gerontologist 2016;56(5):e70-88. https://doi.org/10.1093/geront/gnw078

Muistisairaudet: Käypä hoito -suositus. Suomalaisen Lääkäriseuran Duodecimin, Societas Gerontologica Fennican, Suomen Geriatrit -yhdistyksen, Suomen Neurologisen Yhdistyksen, Suomen Psykogeriatrisen Yhdistyksen ja Suomen Yleislääketieteen Yhdistyksen asettama työryhmä, 2020 Internet:

https://www.kaypahoito.fi/hoi50044 (viitattu 12.3.2021).

Parker D, Mills S, Abbey J. Effectiveness of interventions that assist caregivers to support people with dementia living in the community: a systematic review. Int J Evid Based Healthc 2008;6(2):137-72. https://doi.org/10.1111/ j.1744-1609.2008.00090.x

Peel E, Harding R. 'It's a huge maze, the system, it's a terrible maze': dementia carers' constructions of navigating health and social care services. De- 
mentia 2014;13(5):642-61. https://doi.org/10.1177/1471301213480514

Phillipson L, Jones S, Magee C. A review of the factors associated with the non-use of respite services by carers of people with dementia: Implications for policy and practice. Health Soc Care Community 2014;22(1):1-12. https://doi.org/10.1111/hsc.12036

Puusa A. Näkökulmia laadullisen aineiston analysointiin. Teoksessa: Puusa A, Juuti P, Aaltio I toim. Laadullisen tutkimuksen näkökulmat ja menetelmät. Helsinki: Gaudeamus, 2020: luku 9.

Pöysti MM, Laakkonen ML, Strandberg T, Savikko N, Tilvis RS, Eloniemi-Sulkava U, Pitkälä KH. Gender differences in dementia spousal caregiving. Int J Alzheimers Dis 2012:e162960. https://doi.org/10.1155/2012/162960

Reilly S, Miranda-Castillo C, Malouf R, Hoe J, Toot S, Challis D, Orrell M. Case management approaches to home support for people with dementia. Cochrane Database Syst Rev 2015;1(1):CD008345. https://doi. org/10.1002/14651858.CD008345.pub2

Salo U. Simsalabim, sisällönanalyysi ja koodaamisen haasteet. Teoksessa: Aaltonen S, Högbacka R, toim. Umpikujasta oivallukseen: Refleksiivisyys empiirisessä tutkimuksessa. Tampere: Tampere University Press. 2015:166-90.

Silvasti T. Sisällönanalyysi. Teoksessa: Massa I, toim. Polkuja yhteiskuntatieteelliseen ympäristötutkimukseen. Helsinki: Gaudeamus, 2014: 3349.

Sointu L. Läsnäolo hoivan arjessa. Janus 2011; 19(2):158-73. Internet: https://journal.fi/janus/ article/view/50610 (viitattu 13.3.2021).

Sointu L. Hoiva suhteessa: Tutkimus puolisoaan hoivaavien arjesta. Acta Electronica Universitatis Tamperensis. Tampere: Tampereen yliopisto, 2016. http://urn.fi/URN:ISBN:978-952-03-0190-3

Sosiaali- ja terveysministeriö. Kansallinen muistiohjelma 2012-2020: Tavoitteena muistiystävällinen Suomi. Helsinki, 2012. http://urn.fi/URN:ISBN:978-952-00-3224-1

Stephan A, Bieber A, Hopper L, Joyce R, Irving K, Zanetti $\mathrm{O}$, et al. Barriers and facilitators to the access to and use of formal dementia care: findings of a focus group study with people with dementia, informal carers and health and social care professionals in eight European countries. BMC Geriatr, 2018;18:e131. https://doi.org/10.1186/s12877-018-0816-1

Stirling C, Andrews S, Croft T, Vickers J, Turner, Robinson A. Measuring dementia carers' unmet need for services - an exploratory mixed method study. BMC Health Serv Res 2010;10:e122. https://doi.org/10.1186/1472-6963-10-122

Stolt M, Suhonen R, Koskenniemi J, Hupli M, Katajisto J, Leino-Kilpi H. Läheisen kuormittuneisuus muistipotilaiden kotihoidossa. Hoitotiede 2014;26(2):125-35. https://urn.fi/URN:NBN:fi:ELE-1641663

Tam-Tham H, Cepoiu-Martin M, Ronksley P, Maxwell C, Hemmelgarn B. Dementia case management and risk of long-term care placement: a systematic review and meta-analysis. Int J Geriatr Psychiatry 2013;28(9):889-902. https://doi.org/10.1002/gps.3906

Tatangelo G, Mccabe M, Macleod A, You E. "I just don't focus on my needs." The unmet health needs of partner and offspring caregivers of people with dementia: a qualitative study. Int J Nurs Stud 2018;77:8-14. https://doi.org/10.1016/j.ijnurstu.2017.09.011

Tilastokeskus. Suomen virallinen tilasto. Väestön tieto- ja viestintätekniikan käyttö. 2020. Internet: https://www.stat.fi/til/sutivi/2020/sutivi_2020_2020-11-10_tie_001_fi.html (viitattu 20.3.2021).

Tolhurst E, Carey M, Weicht B, Kingston P. Is living well with dementia a credible aspiration for spousal carers? Health Sociol Rev 2019;28(1):54-68. https://doi.org/10.1080/14461242.2018.1475249

Tommola S, Teiska M, Tamminen A, Alastalo H, Hammar T, Viljamaa S. Muistibarometri 2020. (2021). Helsinki: Muistiliitto, 2021. Internet: https://www.muistiliitto.fi/application/files/8116/1120/9916/Muistibarometri_2020_ saavutettava.pdf (viitattu 28.4.2021).

Turjamaa R, Salpakari J, Koskinen L. Experiences of older spousal caregivers for caring a person with a memory disorder. Healthcare 2020;8(2):e95. https://doi.org/10.3390/healthcare8020095

Van Aerchot L, Eskola P, Aaltonen M. Muistisairaiden ja puoliso-omaishoitajien kokemuksia tuen riittämättömyydestä. Gerontologia 2021;35(3):264-82.

https://doi.org/10.23989/gerontologia.99262

Vecchio N, Fitzgerald J, Radford K, Fisher R. The association between cognitive impairment and community service use patterns in older people living in Australia. Health Soc Care Community 
2016;24(3):321-33.

https://doi.org/10.1111/hsc.12212

Vecchio N, Fitzgerald JA, Radford K, Kurrle S. Respite service use among caregivers of older people: comparative analysis of family dementia caregivers with musculoskeletal and circulatory system disorder caregivers. Aging Ment Health 2018;22(1):92-9.

https://doi.org/10.1080/13607863.2016.1232368

Wennberg A, Dye C, Streetman-Loy B, Pham H. Alzheimer's patient familial caregivers: a review of burden and interventions. Health Soc Work 2015;40(4):162-9. https://doi.org/10.1093/hsw/hlv062

Werner S, Goldstein S, Karpas S, Chan S, Lai, S. Help-seeking for dementia: a systematic review of the literature. Alzheimer Dis Assoc Disord 2014;28(4):299-310. https://doi.org/10.1097/ WAD.0000000000000065
Wolfs C, De Vugt M, Verkaaik M, Verkade P, Verhey F. Empowered or overpowered? Service use, needs, wants and demands in elderly patients with cognitive impairments. Int J Geriatr Psychiatry 2010;25(10):1006-12. https://doi.org/10.1002/gps.2451

Wu Y, Clare L, Hindle J, Nelis S, Martyr A, Matthews F. Dementia subtype and living well: results from the Improving the experience of Dementia and Enhancing Active Life (IDEAL) study. BMC Med 2018;16:e140. https://doi.org/10.1186/s12916-018-1135-2

Zwaanswijk M, Peeters J, Van Beek A, Meerveld J, Francke A. Informal caregivers of people with dementia: problems, needs and support in the initial stage and in subsequent stages of dementia: a questionnaire survey. Open Nurs J 2013;7:6-13. https://doi.org/10.2174/1874434601307010006 